\title{
RANCANG BANGUN SISTEM PEMANTAUAN KEAMANAN GEDUNG BERBASIS IP KAMERA DENGAN FACEBOOK SEBAGAI MAIN BASED-REPOSITORY
}

\author{
Robinson A. Wadu, ST., MT \\ Staff Pengajar pada Program Studi Teknik Komputer dan Jaringan, \\ Politeknik Negeri Kupang \\ Email : robinwadu@gmail.com
}

\begin{abstract}
Abstrak
Perkembangan Teknologi informasi dan jaringan internet saat ini, memunculkan banyak aplikasi-aplikasi web yang sangat penting baik untuk perusahaan maupun perorangan, dimana dengan aplikasi-aplikasi ini kebutuhan akan berkomunikasi antara satu dengan yang lainnya dapat diwujudkan secara mudah dan cepat tanpa memperhitungkan masalah waktu dan jarak. Aplikasi-aplikasi web tersebut dapat berupa aplikasi untuk meyajikan informasi tentang suatu badan perusahaan, informasi pribadi, lembaga pendidikan, dan aplikasi khusus lainnya seperti aplikasi sistem keamanan untuk melakukan pemantauan terhadap kondisi lingkungan tertentu dengan memanfaatkan teknologi kamera seperti Closed-Circuit TeleVision (CCTV), Internet Protocol (IP) Kamera, dan lain-lain.

Penelitian ini dibuat dan dilaksanakan untuk melakukan proses pemantauan terhadap kondisi gedung dengan menggunakan IP kamera Foscam FI8918W dan datanya diolah untuk ditampilkan sebagai status informasi di Aplikasi Facebook dan website online dalam bentuk galeri foto.

Hasil pengujian menunjukkan bahwa ketika terjadi proses penangkapan gambar oleh IP kamera, maka aplikasi web yang dibuat akan mengkondisikan secara otomatis untuk melakukan proses penyimpanan ke komputer server lokal dan sekaligus melakukan proses upload dan update status informasi waktu pengambilan gambar ke facebook, kemudian bagian aplikasi web online berfungsi untuk melakukan proses sinkronisasi dengan memanfaatkan API facebook yaitu Facebook Query Language (FQL)terhadap repository galeri foto yang ada pada facebook untuk ditampilkan sebagai galeri foto pada website online yang dibuat.
\end{abstract}

Kata Kunci : Sistem Pemantauan, IP Kamera, Facebook, API Facebook

\section{PENDAHULUAN}

Perkembangan Teknologi informasi dan jaringan internet saat ini, memunculkan banyak aplikasi-aplikasi web yang sangat penting baik untuk perusahaan maupun perorangan, dimana dengan aplikasi-aplikasi ini kebutuhan akan berkomunikasi antara satu dengan yang lainnya dapat diwujudkan secara mudah dan cepat tanpa memperhitungkan masalah waktu dan jarak. Aplikasi-aplikasi web tersebut dapat berupa aplikasi untuk meyajikan informasi tentang suatu badan perusahaan, informasi pribadi, lembaga pendidikan, dan lain-lain, aplikasi jual beli, aplikasi yang berhubungan dengan lingkungan seperti aplikasi informasi keadaan cuaca, aplikasi pemantau keadaan suatu wilayah tertentu, aplikasi media sosial seperti Facebook, Twitter, dan lain-lain, dan aplikasi khusus lainnya seperti aplikasi sistem keamanan untuk melakukan pemantauan terhadap kondisi lingkungan 
tertentu dengan memanfaatkan teknologi kamera seperti Closed-Circuit TeleVision (CCTV), Internet Protocol (IP) Kamera, dan lain-lain.

Perkembangan aplikasi sistem pemantauan kondisi lingkungan tertentu berbasis teknologi kamera ini sudah mengalami perkembangan yang cukup pesat. Kalau sebelumnya aplikasi sistem ini memanfaatkan kamera CCTV yang terhubung ke DVR (Digital Video Recorder), lalu melalui DVR dihubungkan ke komputer/televisi untuk menangkap hasil kamera dan hanya dapat dipantau pada jarak yang dekat dan pergerakan kamera yang tidak bisa diatur, maka sekarang aplikasi sistem keamanan pemantau kondisi lingkungan tertentu itu sudah memanfaatkan teknologi kamera yang menggunakan protokol jaringan komputer, yang sering disebut dengan kamera jaringan atau IP kamera.

IP kamera merupakan CCTV kamera yang menggunakan Internet Protokol untuk mengirimkan data gambar dan sinyal kendali atas Fast Ethernet Link ${ }^{[1]}$. Dengan demikian sebenarnya IP kamera merupakan pengembangan dari CCTV. Perbedaan besar diantara keduanya terletak pada kamera yang memiliki alamat IP dan web server yang sudah terintegrasi langsung pada modul sistem kamera tersebut.

Saat ini, penggunaan ip kamera sudah berkembang dengan sangat pesat mulai dari implementasi untuk sistem pemantau keamanan lingkungan ruangan atau luar ruangan disaat siang atau malam hari sampai pada penggunaan ip kamera sebagai media autentifikasi untuk sistem keamanan gedung, dan lain sebagainya.

Salah satu kendala besar dari penggunaan kamera baik itu CCTV ataupun IP kamera untuk sistem pemantauan adalah disisi ketersediaan media penyimpanan, dimana pada sisi ini juga akan berpengaruh pada tingkat kemahalan produk. Kalau dikondisikan kamera tersebut dapat melakukan semua fitur perekaman baik video ataupun gambar, maka otomatis media penyimpanan yang diperlukan adalah yang berkapasitas besar dan juga diperlukan teknologi untuk melakukan proses switching otomatis bila salah satu media penyimpanan tersebut mengalami kendala saat dimana tidak ada space atau ruang untuk menyimpan hasil capturing dari kamera tersebut. Problematika seperti ini selain akan memakan biaya untuk membangun sistem dengan kapasitas media penyimpanan yang besar juga biasanya akan mempengaruhi kinerja dari sistem pemantauan yang ada baik disisi performansinya ataupun pada sisi ketepatan dan ketelitian untuk menghasilkan rentetan data yang diperlukan untuk proses pengawasan.

Penelitian ini menawarkan suatu teknologi sistem yang memanfaatkan sumber external storage yang tersedia secara besar dan global 
yang dapat diakses kapan saja yaitu dengan memanfaatkan sistem storage atau repository dari media sosial seperti facebook, dan lainlain. Dengan memanfaatkan sistem repositori pada media sosial tersebut diharapkan tingkat kestabilan penyediaan sumber data pengawasan hasil pengolahan tangkapan kamera akan tetap terjaga dengan baik. Sistem yang dibangun ini juga nanti dapat dimanfaatkan.

Pemilihan Facebook sebagai media informasi karena menurut Anand Tilak, Head of Facebook Indonesia, bahwa jumlah pengguna aktif Facebook di Indonesia tiap bulannya mencapai 69 juta orang ${ }^{[5]}$, ini berarti bahwa media sosial ini sangat besar diminati oleh pengguna diIndonesia bahkan didunia. Media sosial ini dipakai selain sebagai media informasi diri tentang status pribadi dan sosial juga dipakai sebagai media informasi marketing yang berfungsi untuk menampilkan suatu informasi penawaran dan penjualan terhadap produk tertentu.

\section{TUJUAN DAN RUANG LINGKUP PENELITIAN}

\section{a. Tujuan Penelitian}

Tujuan penelitian ini adalah :

a. Merancang dan membuat suatu model teknologi pemantau untuk kondisi lingkungan gedung menggunakan IP kamera yang dapat diatur melalui web sekaligus berintegrasi dengan media sosial facebook sebagai media informasi dan penyimpan hasil perekaman kameranya.

b. Membuat teknologi Interface yang dapat membuat sistem dapat terintegrasi secara langsung dan otomatis dengan media sosial facebook sebagai media informasi dan penyimpan perekaman kameranya.

\section{b. Ruang Lingkup Penelitian}

Ada beberapa bagian yang dibahas pada penelitian ini adalah:

1. Pembuatan aplikasi sistem pemantau keamanan gedung dengan IP kamera ini menggunakan aplikasi berbasis web yang hanya digunakan pada server dengan sistem operasi Linux.

2. Integrasi antara aplikasi web ini dengan media sosial facebook hanya sebatas informasi gambar yang diambil oleh IP kamera terhadap kondisi lingkungan gedung yang ada.

3. Proses pengambilan gambar oleh IP kamera dilakukan berdasarkan prosedur pengaturan waktu otomatis maupun waktu manual yang diatur oleh aplikasi webnya.

4. Pembuatan web online berupa galeri foto hasil pengambilan data secara realtime dari galeri foto media sosial facebook.

\section{API FACEBOOK}

API singkatan dari Application Programming Interface. Facebook API merupakan antar muka pemrograman web services (web 
services programming interface) untuk mengakses layanan utama Facebook (login, redirect, update view). API ini berbasis arsitektur REST (Representational State Transfer).

\section{IV.IP KAMERA}

IP Kamera merupakan perkembangan dari CCTV, yang membedakan dari CCTV biasa adalah setiap kamera mempunyai IP sendiri sehingga dapat memilih sendiri IP Kamera mana yang mau dilihat. IP Kamera memungkinkan pemilik rumah atau bisnis untuk melihat kamera mereka melalui koneksi internet yang tersedia melalui komputer atau mobile phone yang mendukung $3 \mathrm{G} .{ }^{[4]}$

\section{Format Kompresi IP Kamera}

\section{a. MJPEG (Motion Joint Photographic} Experts Group $)^{[1][3][4]}$

Motion JPEG (MJPEG) adalah nama tidak resmi untuk kelas format video dimana tiap frame atau bidang tautan dari urutan video digital yang secara sederhana dikompres menjadi gambar JPEG. Secara sederhana dikembangkan untuk aplikasi PC multimedia, dimana format yang lebih canggih telah menggantikannya. Beberapa karakterisktik dari MJPEG antara lain :

a. Mempunyai Ekstensi .mjpeg atau mjpg

b. Berisi kumpulan dari jpg-jpg

c. Diawali dengan header : --myboundary content length:[ukuran jpeg pada bagian ini] content-type: image/jpeg.

Dimana content-length menjelaskan besar ukuran jpeg pada bagian itu dalam byte, dan header tersebut akan diulang kembali setelah akhir dari jpeg tersebut

\begin{tabular}{|c|c|}
\hline 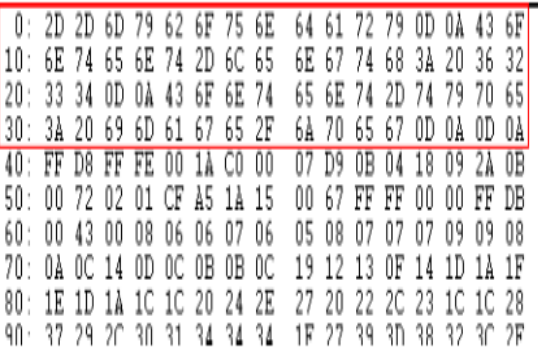 & 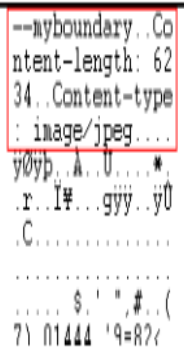 \\
\hline
\end{tabular}

Gambar 5.1 Contoh header MJPEG

\section{VI.PERANCANGAN}

Arsitektur sistem yang dibangun untuk pemantauan menggunakan IP kamera ini dibedakan menjadi dua bagian yaitu sistem yang bekerja dan diakses secara lokal, yaitu sistem yang tidak terhubung dengan internet dan sistem yang dibangun untuk media informasi bagi pengguna yang menggunakan internet melalui Facebook dan akses website online.

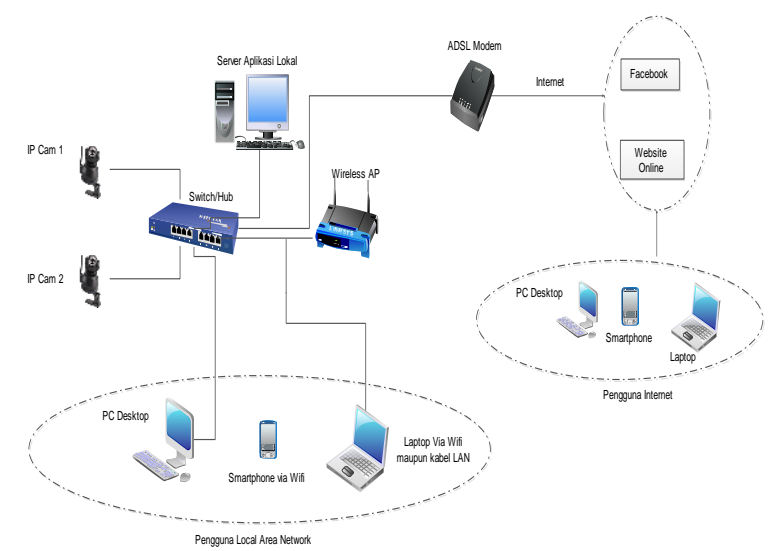

Gambar 6.1 Rancangan Arsitektur Sistem IP Kamera

Berdasarkan gambar 6.1 diatas, fungsi dari beberapa komponen pentingnya adalah sebagai berikut : 
1. IP kamera yang digunakan merupakan kamera stand alone, yang mempunyai konfigurasi alamat IP yang berbeda-beda. Dengan kamera jenis ini pengguna dapat secara langsung mengakses streaming IP kamera tersebut dari manapun via jaringan lokal maupun internet dengan menggunakan web browser standar dan melalui aplikasi yang dirancang dan dibuat. Keseluruhan sistem yang ada di dalam IP kamera ini sudah digitalisasi dimana didalamnya sudah terdapat prosesor untuk memproses gambar digital dan program web server untuk menampilkannya ke web browser pengguna. Walaupun demikian, dalam penelitian ini penulis tidak memanfaatkan web server bawaan serta aplikasi bawaan yang ada didalam IP kamera tersebut, melainkan menggunakan aplikasi sendiri yang dirancang dan dibuat dengan menggunakan bahasa pemograman PHP.

2. Sebuah PC server aplikasi lokal yang merupakan bagian penting dalam arsitektur ini berfungsi untuk menghasilkan streaming gambar dalam format MJPEG (Motion-JPEG) dan sekaligus sebagai storage recording yang memiliki peran dalam sisi mekanisme penyimpanan gambar dari hasil pemantauan IP kamera.

3. Switch/Hub berfungsi sebagai media penghubung komunikasi antara satu komponen dengan komponen lainya dalam jaringan komputer.

4. Wireless AP merupakan alat transmisi tanpa kabel yang berfungsi untuk mentransmisikan data dari bagian sumber ke bagian penerima dengan memanfaatkan frekuensi radio. Dalam penelitian ini wireless AP dipakai sebagai media transmisi bagi pengguna yang hanya dapat mengakses IP kamera secara wireless, seperti smartphone maupun laptop yang memanfaatkan fungsi wirelessnya untuk berkomunikasi.

5. Modem/Modem ADSL, berfungsi sebagai media penghubung ke dunia internet. Dalam penelitian ini, karena hasil pengambilan gambar oleh IP kamera ingin ditampilkan sebagai informasi dihalaman facebook dan website online maka bagian ini diperlukan untuk mewujudkannya.

6. Karena terdapat website online sinkronisasi dengan galeri foto pada facebook maka terdapat server hosting, dimana aplikasi sinkronisasi dihosting pada server hosting tersebut, sehingga pengguna yang tidak memiliki akun facebook juga dapat melihat yang sama kondisi keadaan gedung melalui kumpulan gambar-gambar hasil sinkronisasi dengan facebook .

Perancangan perangkat lunak aplikasi web dimodelkan dengan menggunakan UML, dimana yang ditampilkan dalam penelitian ini 
adalah dalam bentuk Use Case Diagram dan Diagram Activity.

\section{Perancangan Use Case Diagram}

Use case diagram ini bertujuan agar permasalahan sistem dapat dijabarkan dalam obyek-obyek kecil dan untuk memodelkan dan menyatakan fungsi yang disediakan oleh sistem pemakai. Use case diagram dari aplikasi web yang dibuat adalah sebagai berikut :

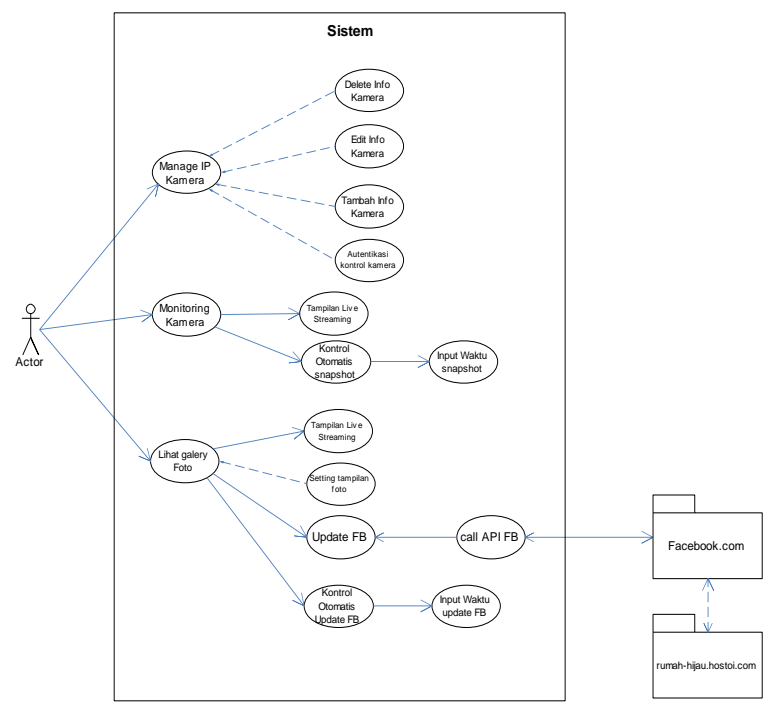

Gambar 6.2 Use Case Diagram Aplikasi Web

Penjelasan secara detil terhadap use case diagram aplikasi web adalah sebagai berikut :

a. Use case Manage IP Kamera

Pada bagian ini actor atau pengguna dapat melakukan pengaturan terhadap inisialisasi IP kamera termasuk proses autentikasi untuk pengaturan kontrol kamera berupa pengaturan gerak, resolusi kamera,kamera preset,dan lain-lain

b. Use case Monitoring IP Kamera

Pada bagian ini akan ditampilkan kondisi live streaming dari kamera aktif yang ditampilkan secra grid yang dapat diatur oleh pengguna dan pengaturan waktu untuk proses rekam otomatis snapshot oleh IP kamera yang akan disimpan pada server.

c. Use case Lihat Galeri Foto

Bagian ini akan ditampilkan foto hasil snapshot/pengambilan gambar otomatis berdasarkan waktu yang diatur oleh pengguna dimana tampilan galeri fotonya berdasarkan waktu hari dan jam pengambilan gambar. Bagian ini juga menyediakan fungsi bagi pengguna untuk melakukan update informasi foto ke halaman facebook secara manual dan otomatis.

\section{Perancangan Activity Diagram}

Berikut ini akan ditampilkan diagram activity dari aplikasi web yang dibuat untuk menjelaskan tentang proses kerja dari program yang ditunjukkan pada gambar 6.2 diatas. Diagram activity dari web aplikasi ini dibagi menjadi dua bagian yaitu bagian live streaming monitoring kamera dan galeri foto a. Live Streaming Monitoring Kamera 


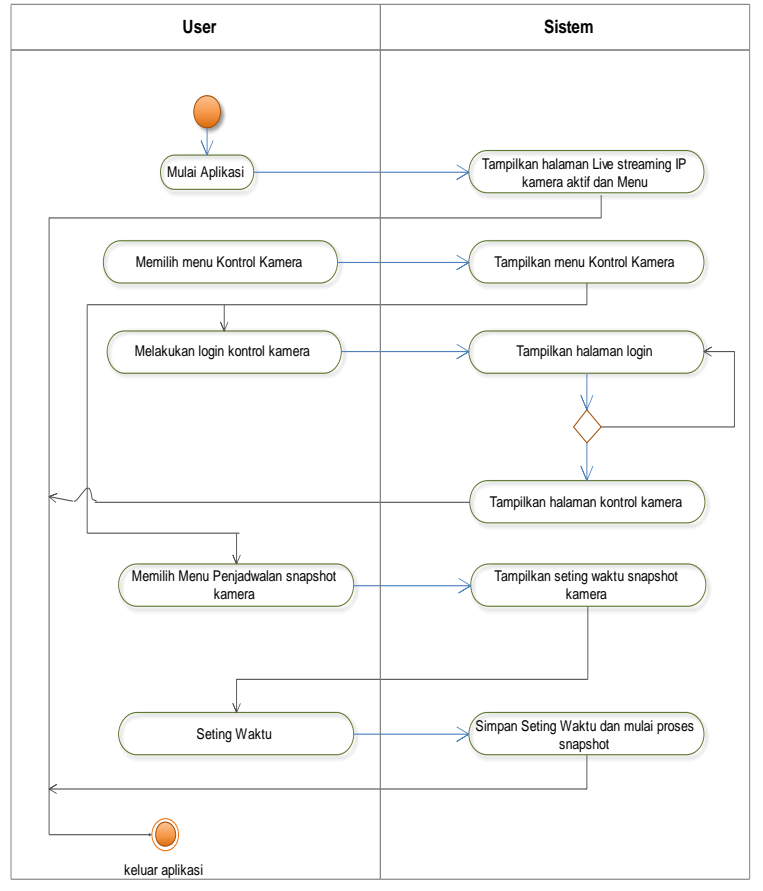

Gambar 6.3 Diagram activity streaming IP Kamera

b. Galeri foto

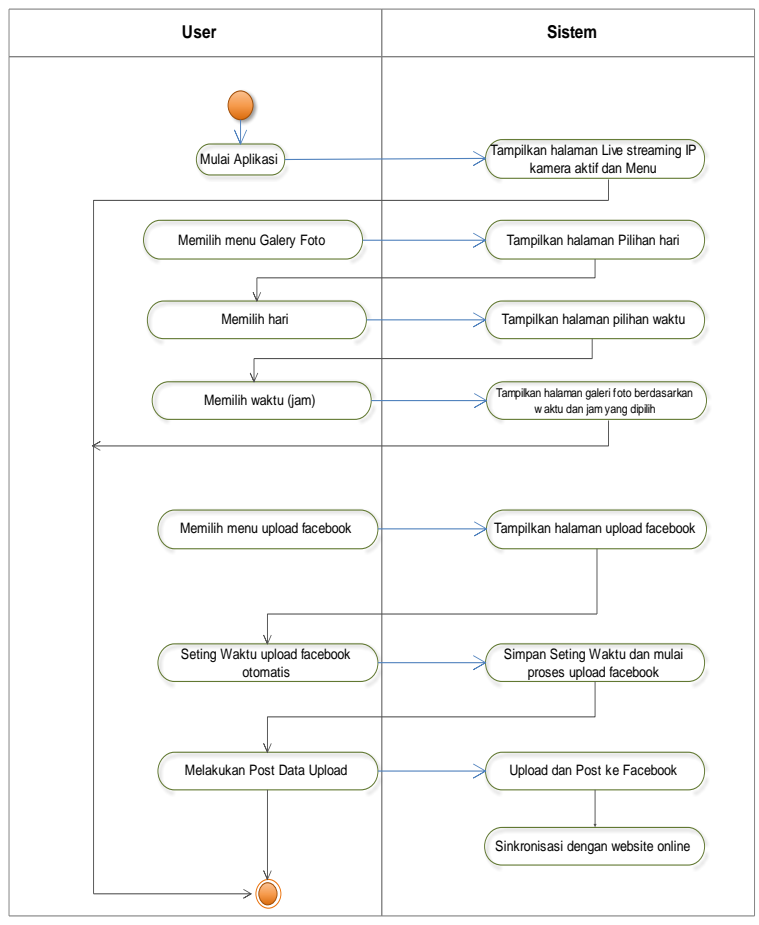

Gambar 6.4 Diagram activity galeri foto

\section{Proses Interaksi Aplikasi dengan Facebook}

Facebook digunakan sebagai media penyebaran informasi dan pemantauan kondisi aktifitas dalam gedung. Proses dilakukan dengan meng-interaksikan aplikasi dengan facebook.

Mekanisme proses interaksi ke facebook ditunjukkan pada blog diagram pada Gambar berikut

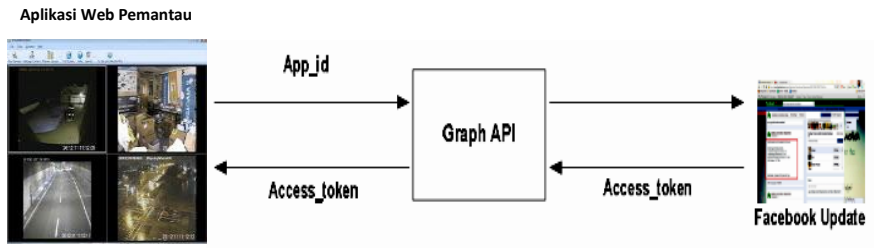

Gambar 7.1 Diagram blok interaksi aplikasi ke Facebook

Alur kerja program untuk melakukan upload dan update status di halaman Facebook adalah sebagai berikut :

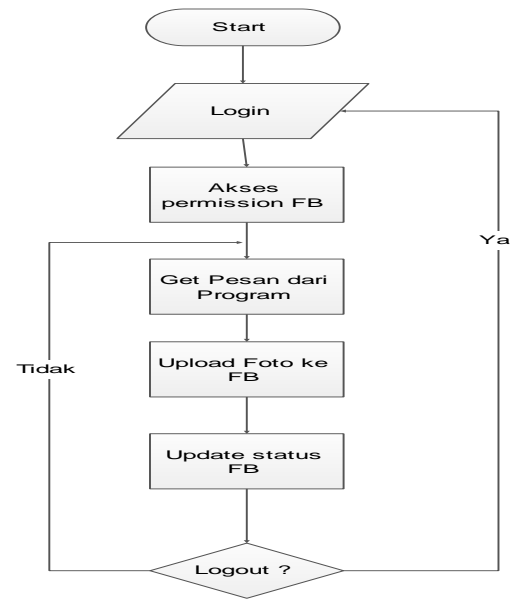

Gambar 7.2 Diagram alir program upload dan update Facebook

Proses upload dan update status facebook dimulai dengan melakukan login secara otomatis terhadap akun facebook yang sudah dibuat aplikasinya berdasarkan API facebook, dimana data tentang aplikasi facebook baik app_id, Secret_id, Access_token, fanpage_id, page_access_token sudah diperoleh 
sebelumnya dan diinputkan ke program aplikasinya, lalu program aplikasi melakukan invoke HTTP POST kepada endpoint dari facebook graph AP. Selanjutnya facebook melakukan crawling terhadap objek dari halaman aplikasi, membaca metadata, dan menyambungkan dengan objek - objek terkait yang telah diberi autentifikasi. Akses permission dibutuhkan untuk mendapatkan hak akses pada scope yang direquest dan ini merupakan penanda bahwa telah diberikan hak akses penuh ke facebook. Kemudian program akan melakukan proses upload foto ke facebook sekaligus melakukan update status facebook secara otomatis yang telah dijadwalkan.

\section{Proses Interaksi Facebook dengan Web Hosting}

Proses interaksi facebook dengan web hosting sebagai website online sinkronisasi dilakukan dengan memanfaatkan API dari facebook dan FQL (Facebook Query Language). Mekanisme interaksi facebook dengan web hostingnya ditunjukkan pada gambar blok diagram berikut

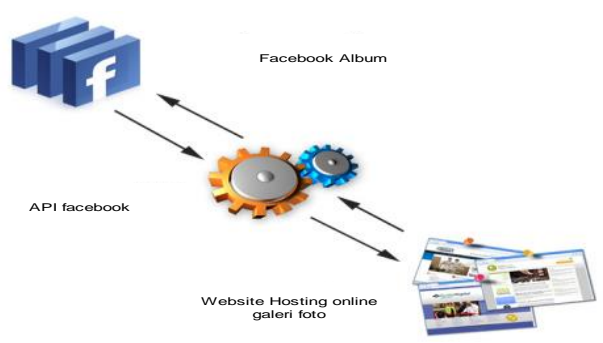

Gambar 8.1 Diagram blok interaksi aplikasi Facebook dengan web hosting

\section{IX.HASIL PENGUJIAN}

1. Pengujian Bagian Awal Koneksi Sistem Aplikasi Web dengan IP Kamera

Pengujian terhadap aplikasi web yang dibuat dengan memastikan komunikasi antara server dan IP kamera berjalan dengan baik yaitu dengan melakukan proses ping antara server dengan alamat IP dari IP kamera yang ada. Setelah semua kondisi sudah terpenuhi, berikut ada beberapa langkah yang dilakukan untuk menguji sistem yang dibuat :

1. Pengguna melakukan permintaan hubungan pertama dengan server dengan cara mengakses pada alamat server yang dituju yaitu http://10.42.0.1/kamera/utama/index.html pada web browser yang ada di pengguna. Jika server web mengirim dokumen apache ke browser web, maka pengguna dan server telah terhubung dalam jaringan yang sama.

2. Server akan memberikan respons awal dengan menampilkan halaman otentifikasi untuk pengguna dapat mengakses alamat IP dari IP kamera yang terhubung dalam jaringan.

3. Bila proses otentifikasi berhasil maka server akan menampilkan halaman utama streaming dari IP kamera yang aktif. Gambar hasil pengujian dapat dilihat pada gambar 9.1 berikut 


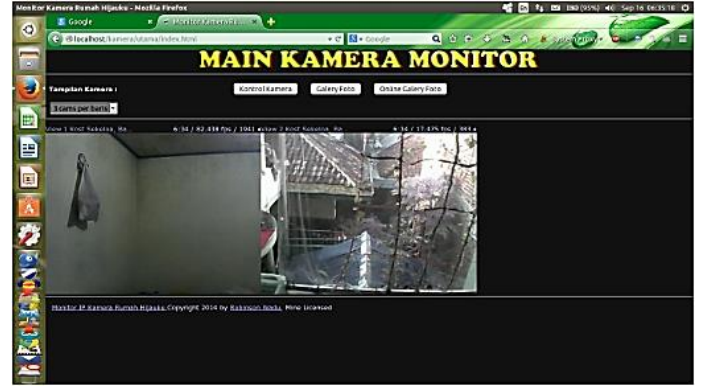

Gambar 9.1 Halaman awal pengujian IP kamera berhasil Tampil di web browser

Tabel 9.1 Pengujian akses IP kamera Aktif oleh Aplikasi Web

\begin{tabular}{|c|c|c|}
\hline No & $\begin{array}{c}\text { Otentifikasi IP } \\
\text { Kamera }\end{array}$ & Status \\
\hline 1 & Proses & $\begin{array}{c}\text { Streaming IP } \\
\text { kamera 1 } \\
\text { berhasil }\end{array}$ \\
\hline 2 & Prontifikasi IP & kamera 1 \\
& IP kamera 2 & $\begin{array}{c}\text { Streaming IP } \\
\text { kamera 2 } \\
\text { berhasil }\end{array}$ \\
\hline
\end{tabular}

Dari hasil pengujian yang dilakukan menunjukkan bahwa IP kamera 1 dan IP kamera 2 terhubung dengan baik pada jaringan komputer yang ada dan dapat merespon permintaan streaming dari pengguna bila proses otentifikasi berhasil dilakukan.

\section{Pengujian Bagian Kontrol kamera dan Penjadwalan Pengambilan gambar IP kamera}

Pengujian terhadap kontrol kamera dan penjadwalan pengambilan gambar IP kamera bertujuan untuk memastikan sistem aplikasi dapat melakukan kontrol terhadap pergerakan kamera secara manual dan memastikan fungsi crontab pada Linux Ubuntu dapat diseting melalui aplikasi interface web. Pada implementasi penjadwalan dibuat sebuah file SSH dari PHP untuk mengakses crontab.

Prosedur pengujiannya adalah sebagai berikut :

\section{Pengujian Kontrol kamera}

a. Pengguna melakukan permintaan hubungan pertama kali dengan server yaitu dengan mengakses alamat server untuk kontrol kamera pada browser web yaitu http://10.42.0.1/kamera/kamerakontrol/Operator.htm. Jika server web mengirim dokumen apache browser, maka pengguna dan server telah terhubung dalam satu jaringan.

b. Pengguna melakukan aksi pengontrolan gerak IP kamera yang aktif pada tombol navigasi yang ada.

c. Jika berhasil, maka IP kamera akan memberikan respon dengan bergerak sesuai dengan tombol navigasi yang dieksekusi. Gambar hasil pengujian aplikasi web untuk pengontrolan kamera dapat dilihat pada gambar 9.2 berikut.

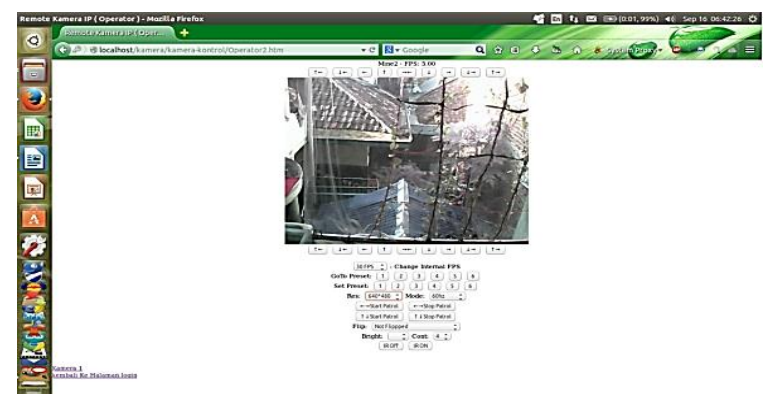

Gambar 9.2 Halaman pengontrolan IP kamera aktif 
Tabel 9.2 Hasil Pengujian Respon Gerak oleh IP kamera dari Aplikasi

\begin{tabular}{|l|l|}
\hline \multicolumn{1}{|c|}{ Pengujian } & \multicolumn{1}{c|}{$\begin{array}{c}\text { Respon Gerak IP } \\
\text { Kamera }\end{array}$} \\
\hline $\begin{array}{l}\text { Eksekusi tombol } \\
\text { navigasi kiri }\end{array}$ & $\begin{array}{l}\text { IP kamera bergerak } \\
\text { ke arah kiri }\end{array}$ \\
\hline $\begin{array}{l}\text { Eksekusi tombol } \\
\text { navigasi kanan }\end{array}$ & $\begin{array}{l}\text { IP kamera bergerak } \\
\text { ke arah kanan }\end{array}$ \\
\hline $\begin{array}{l}\text { Eksekusi tombol } \\
\text { navigasi atas }\end{array}$ & $\begin{array}{l}\text { IP kamera bergerak } \\
\text { ke arah atas }\end{array}$ \\
\hline $\begin{array}{l}\text { Eksekusi tombol } \\
\text { navigasi bawah }\end{array}$ & $\begin{array}{l}\text { IP kamera bergerak } \\
\text { ke arah bawah }\end{array}$ \\
\hline
\end{tabular}

Dari hasil pengujian terhadap respon gerak IP kamera dengan eksekusi aplikasi web menunjukkan bahwa IP kamera dapat merespon dengan baik terhadap eksekusi perintah gerak berdasarkan arah kanan, kiri, atas maupun bawah.

\section{Pengujian penjadwalan}

Prosedur pengujian yang dilakukan adalah sebagai berikut :

1. Pengguna melakukan permintaan dengan cara mengetikkan pada browser alamat server untuk proses penjadwalan yaitu http://10.42.0.1/kamera/aksi/aturwaktu.ht ml. Jika server web memberikan respon dengan mengirimkan dokumen apache ke web browser pengguna, maka pengguna dan server telah terhubung dalam satu jaringan.

2. Pada saat pengguna melakukan request terhadap alamat wer servernya, maka server akan menanggapinya dengan mengirim hasil eksekusi yaitu menampilkan halaman seting waktu untuk penjadwalan
3. Pengguna melakukan aksi dengan menyeting waktu aktifitas pengambilan gambar oleh IP kamera aktif dan server akan merespons otomatis dengan mengeksekusi pilihan aksi oleh pengguna.

4. Jika berhasil, maka pada halaman crontab di sistem operasi di Linux Ubuntu akan tersimpan hasil setingan waktu sama seperti pada halaman web. Gambar 9.3 berikut adalah halaman seting untuk waktu pengambilan gambar

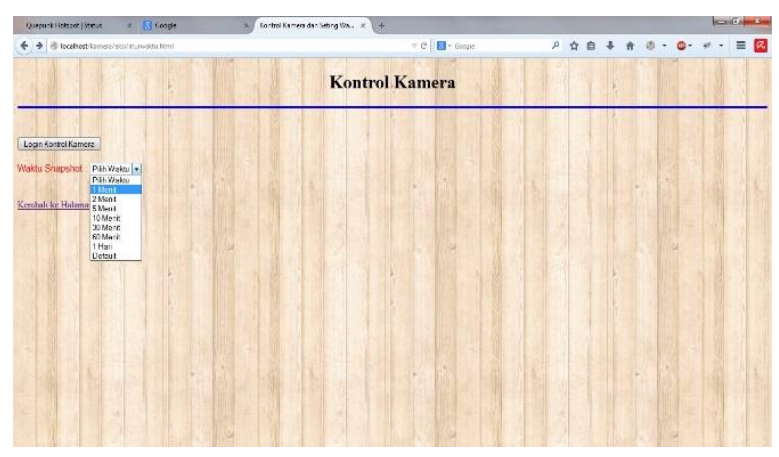

Gambar 9.3 Halaman Penjadwalan Pengambilan Gambar IP kamera

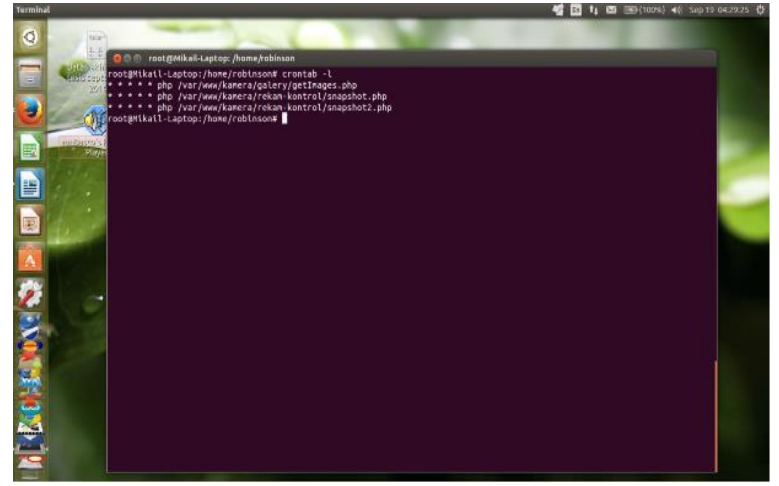

Gambar 9.4 Hasil seting penjadwalan pada crontab oleh aplikasi web 
Tabel 9.3 Hasil Pengujian Seting Penjadwalan dan pengambilan gambar terjadwal menampilkan halaman seting waktu untuk penjadwalan posting ke Facebook.

\begin{tabular}{|c|c|c|c|}
\hline No & Halaman Crontab & Kamera & StatakuHklasekusiksi \\
\hline 1 & $\begin{array}{l}\text { Eksekusi } \text { kontrol } \\
\text { snapshot kamera } 1 \\
\text { dalam crontab }\end{array}$ & IP Kamera 1 & $\begin{array}{l}\text { Berhasil melakukan snapshot sesuai } \\
\text { meenyeing wakju aktifitas upload gambar } \\
\text { jadwal yang dibuat } \\
\text { ke halaman fanpage facebook sekaligus }\end{array}$ \\
\hline 2 & $\begin{array}{l}\text { Eksekusi kontrol } \\
\text { snapshot kamera } 2 \\
\text { dalam crontab }\end{array}$ & IP Kamera 2 & $\begin{array}{l}\text { Berhasil melakukan snapshot sesuai } \\
\text { update status facebook dan server akan } \\
\text { jadwal yang dibuat } \\
\text { merespons otomatis } \quad \text { dengan }\end{array}$ \\
\hline
\end{tabular}

Hasil pengujian dapat diamati bahwa setiap melakukan seting waktu pada aplikasi web yang telah dibuat maka akan terjadi perubahan konfigurasi pada tabel crontab di sistem operasi Linux Ubuntu seperti pada gambar 9.3 dan gambar 9.4 diatas, sehingga dapat disimpulkan bahwa bagian penjadwalan pada aplikasi web yang dibuat dapat digunakan dan berjalan dengan baik.

\section{Pengujian Monitoring ke Facebook}

Pengujian pada bagian ini dimulai dengan mengkoneksikan PC server ke internet. Kemudian prosedur pengujiannya adalah sebagai berikut :

1. Pengguna melakukan permintaan dengan cara mengetikkan pada browser alamat server untuk proses penjadwalan yaitu http://10.42.0.1/kamera/aksi/facebook/atu rfb.html.Jika server web memberikan respon dengan mengirimkan dokumen apache ke web browser pengguna, maka pengguna dan server telah terhubung dalam satu jaringan.

2. Pada saat pengguna melakukan request terhadap alamat web servernya, maka server akan menanggapinya dengan mengirim hasil eksekusi yaitu mengeksekusi pilihan aksi oleh pengguna.

4. Jika berhasil, maka pada halaman crontab di sistem operasi di Linux Ubuntu akan tersimpan hasil setingan waktu sama seperti pada halaman web. Gambar 9.5 berikut adalah halaman seting untuk waktu posting ke facebook

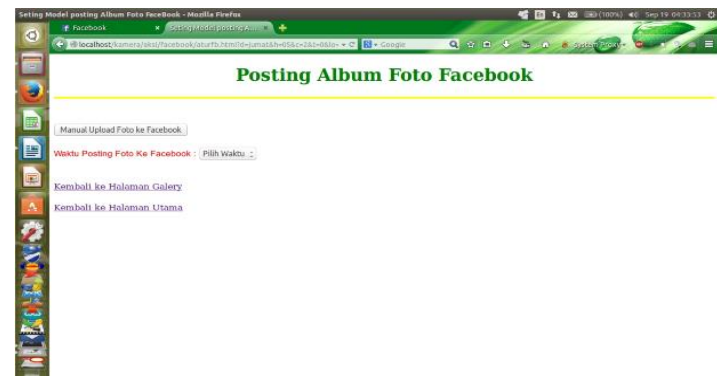

Gambar 9.5 Halaman seting untuk waktu posting ke Facebook

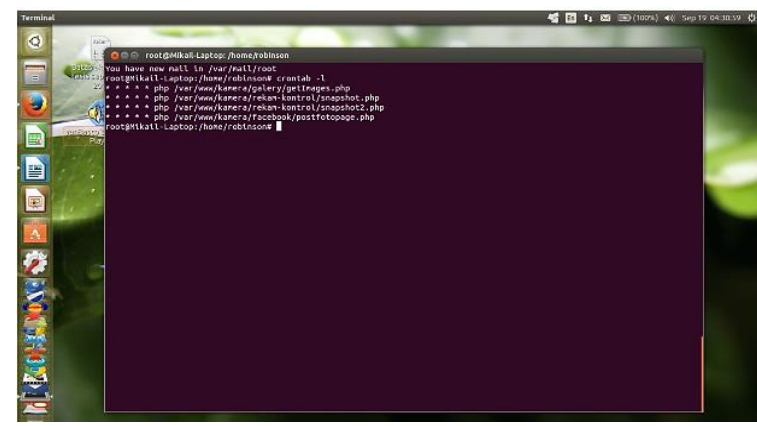

Gambar 9.6 Hasil seting penjadwalan pada crontab oleh aplikasi web

Pada pengujian ini dilakukan sampling sesuai ketersediaan waktu pada halaman seting jadwal pada aplikasi web yang dibuat hasil 
pengujian menunjukkan pada semua seting waktu yang diberikan sistem aplikasi web akan melakukan upload dan update status ke fan page facebook secara otomatis dan berhasil dengan baik.

Hasil capture pengujian posting ke fan page facebook adalah sebagai berikut

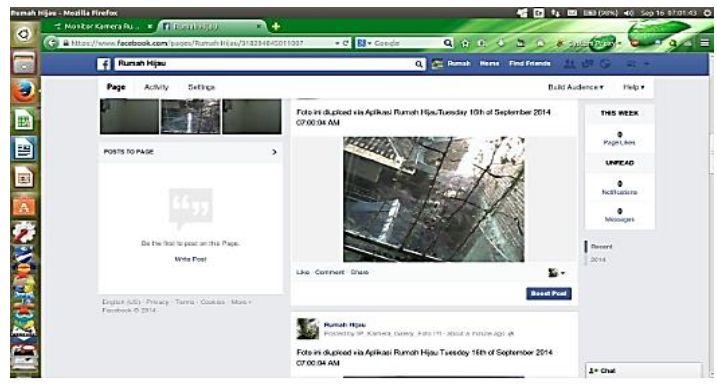

Gambar 9.7 Hasil Posting dan upload gambar ke Facebook

\section{Pengujian Monitoring ke Web Hosting}

Pengujian pada bagian ini adalah dengan mengakses website hosting gratis yang disediakan oleh salah satu web hosting indonesia indowebhost dan menghasilkan url gratis yaitu http://www.rumahhijau.hostoi.com bersamaan pada saat proses posting dan upload gambar ke facebook oleh sistem aplikasi web yang dibuat. Hasilnya ditunjukkan pada gambar 9.8 berikut

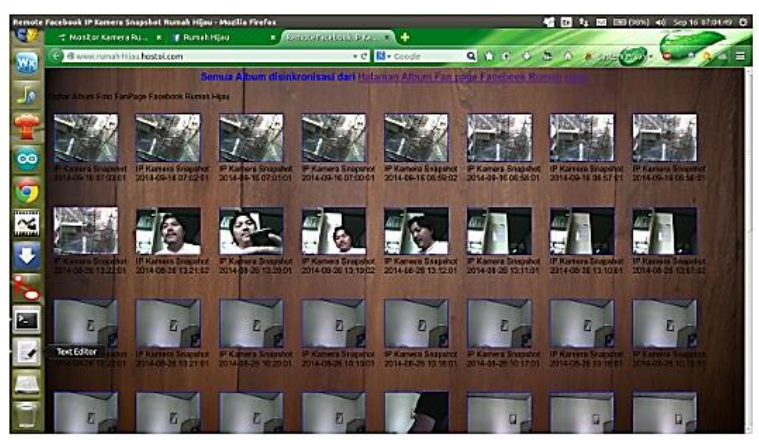

Gambar 9.8 Halaman Website online sinkronisasi dengan Facebook

\section{Pengujian Fungsional Aplikasi Web}

Pengujian fungsionalitas sistem secara keseluruhan dilakukan setelah sistem secara keseluruhan terkonfigurasi secara baik. Pengujian dilakukan hanya berdasarkan setiap fungsi dari sistem aplikasi web yang dibuat. Hal ini bertujuan untuk mengetahui keberhasilan fungsi dari masing-masing bagian dalam sistem. Hasilnya adalah fungsionalitas sistem secara keseluruhan berjalan dengan baik.

\section{KESIMPULAN DAN SARAN}

\section{Kesimpulan}

Kesimpulan dari pengujian sistem yang dibuat adalah sebagai berikut :

1. IP kamera berdasarkan aktifitas kerja dari aplikasi web yang dibuat dapat melakukan kerja pemantauan terhadap kondisi lingkungan gedung dengan baik melalui jaringan LAN.

2. Aplikasi web yang dibuat dapat melakukan rutin penyimpanan data gambar hasil tangkapan gambar oleh IP kamera dan disimpan pada komputer server lokal dengan baik.

3. Aplikasi web yang dibuat merupakan aplikasi yang dibuat menggunakan bahasa pemograman PHP dan hanya berjalan sempurna pada sisem operasi Linux.

4. Secara keseluruhan fungsionalitas aplikasi web sudah dapat berjalan dengan baik dan benar.

5. Hasil pengujian monitoring ke facebook $100 \%$ berhasil mem-post data monitoring 
ke facebook selama koneksi jaringan internet tidak mengalami hambatan.

6. Dengan menggunakan sistem yang dibangun maka pemantauan terhadap kondisi gedung menggunakan IP kamera dapat dilakukan secara otomatis dan hasilnya dapat dilihat oleh semua pengguna yang menggunakan akun facebook aupun tidak.

\section{Saran}

Saran untuk pengembangan sistem pada penelitian ini adalah:

1. Untuk pengembangan selanjutnya dapat dikembangkan metode pemantauan dengan memanfaatkan proses pendeteksian gerak atau aktifitas orang atau manusia yang ada dalam gedung, sehingga sistem tidak secara bebas melakukan proses penyimpanan melainkan proses penyimpanan dilakukan pada saat ada gerakan orang dalam gedung.

2. Untuk lebih mendapatkan tingkat kehandalan yang baik dari aplikasi web yang dibuat dapat ditambahkan fitur-fitur lain seperti penyimpanan video rekaman dan lain-lain menggunakan bahasa pemograman lain.
PUSTAKA

[1]._ About Network Camera and It's Applications, 2012. http://www.axis.com/products/video/cam era/about_cameras/overview.htm, 5 Juli 2017, 19.30 WIB

[2].Abdul Kadir, Terra Ch. Triwahyuni, Pengenalan Teknologi Informasi, ANDI Yogyakarta, 2003

[3].Arfiansyah, Rudi, Yuli Fitrisia S.T, and Mardhiah Fadhli S.T, “Aplikasi Android Untuk Kontrol dan Monitoring Ruangan Menggunakan Ip Camera”. Jurnal Teknik Informatika, Vol. 1, September 2012.

[4].Aryanto bin Amir, Mahmud, IPCamera dan Aplikasinya, Jakarta: Elex Media Komputindo, 2010.

[5].Reska K. Nistanto, Facebook Ungkap Jumlah Penggunanya di Indonesia, 2014. http://tekno.kompas.com/read/2014/09/2 2/15205237/Facebook.Ungkap.Jumlah.P enggunanya.di.Indonesia, 22 September 2017, 21.45 WIB 